\title{
НЕГЛАСНІ СЛІДЧІ (РОЗШУКОВІ) ДІЇ ТА ОПЕРАТИВНО-РОЗШУКОВІ ЗАХОДИ: ЇХ СПІЛЬНІ ТА ВІДМІННІ РИСИ І ПРОБЛЕМИ НОРМАТИВНОГО РЕГУЛЮВАННЯ
}

\author{
ШАЙ Роман - кандидат юридичних наук, доцент, доцент кафедри \\ кримінального права та процесу Інституту права, психології та інноваційної \\ освіти Національного університету «Львівська політехніка». \\ ORCID ID :https://orcid.org/0000-0003-2788-6035 \\ УДК 343.985 \\ DOI 10.32782/EP.2021.4.17
}

Стаття присвячена виявленню проблем при здійсненні негласних слідих (розшукових) дій та оперативно-розиукових заходів. У статті наведено спільні та відмінні риси вказаних правових інститутів, вказано на недоліки їх нормативного регулювання. Як підсумок, відзначається про те, що негласні слідиі (розшукові) діи мають змішану правову природу та поєднують у собі риси як оперативно-розшукових заходів, так $і$ слідиих дій. Крім того, аргументується необхідність більи детального розмежування та законодавчого врегулювання негласних слідчих (розшукових) дій та оперативно-розшукових заходів на законодавчому та відомчому рівнях.

Ключові слова: оперативно-розшукова дiяльність, негласні слідчі (розшукові) дї, оперативно-розшукові заходи, гласна процесуальна діяльність, обіційні процесуальні дї

\section{Постановка проблеми}

3 прийняттям у 2012 році нового КПК у правовій площині з'явився новий інститут - негласні слідчі (розшукові) дії. Раніше така діяльність реалізовувалася у межах проведення оперативно-розшукових заходів, які чітко регламентувалися відповідним законом. Але після 2012 року учасники кримінального процесу стикаються з серйозною проблемою: негласні розшукові дії перебрали на себе певні риси й завдання оперативно-розшукових дій, тому їх спільні та відмінні аспекти потребують обговорення та більш детального врегулювання на законодавчому рівні.

Аналіз останніх досліджень

Питанням нормативного регулювання та співвідношення НСРД та ОРЗ присвятили свої дослідження такі науковці та практики, як: Б.І. Бараненко, І.П. Козьяков, В.А. Колєснік, О.Б. Комарницька, С.С. Кудінов, Д.А. Нескромний, Д.Й. Никифорчук, С.I. Ніколаюк, М.А. Погорецький, В.О. Прядко, В.А. Селюков, Д.Б. Сергєєва, Г.П. Середа, С.Д. Скулиш, В.М. Тертишник, С.Р. Тагієв, А.Г. Цвєтков, М.Є. Шумило, А.Б. Щербаковський та інші. У вказаних наукових працях досліджено загальні положення щодо проведення НСРД та здійснення оперативно-розшукової діяльності. y той же час питання розмежування таких інститутів, як НСРД та ОРЗ, потребує більш детального дослідження.

Виклад основних положень

Суспільство потребує налагодження ефективної роботи системи правоохоронних органів 3 метою розкриття і розслідування кримінальних правопорушень, першочергового поновлення прав потерпілого - особи, якій кримінальним правопорушенням завдано моральної, фізичної або майнової шкоди. Зі змісту норм КПК випливає, що це і $є$ найголовніша мета, якою керувався законодавець, створюючи новий процесуальний кодекс. 
Крім того, головним здобутком КПК слід вважати чіткий розподіл кримінально-процесуальних функцій між окремими учасниками кримінального судочинства та наявність системи стримувань і противаг, які забезпечуватимуть вирішення завдань правосуддя. Проте найбільш революційним кроком законодавця стало впровадження у систему досудового розслідування інституту негласних слідчих (розшукових) дій, що, по суті, є оперативними заходами, спрямованими на конспіративне отримання відомостей про підготовлювані та вчинені злочини з метою їх невідкладного припинення й розкриття [1, с. 108-110]. Саме у зазначеному інституті законодавець передбачив підстави, умови, межі та порядок допустимого втручання держави в особі уповноважених органів в особисті немайнові та майнові права громадян з одночасним передбаченням гарантій, недопущення їх необгрунтованого порушення та для дієвого відновлення.

Отже, до прийняття у 2012 році нового КПК України такого інституту, як НСРД, не існувало. Фактично така діяльність здійснювалася в рамках проведення ОРЗ у процесі оперативно-розшукової діяльності (далі - ОРД) у поєднанні з проведенням слідчих дій. Таким чином, НСРД ввібрали в себе певні риси як ОРЗ, так і слідчих дій.

Враховуючи те, що за правовою природою НСРД є похідними від ОРЗ, варто розпочати 3 визначенням правової природи інституту НСРД в українському законодавстві. Так, ч. 1 ст. 246 КПК України дає чітке визначення поняття НРСД - це різновид слідчих (розшукових) дій, відомості про факт та методи проведення яких не підлягають розголошенню, за винятком випадків, передбачених КПК України [2].

НРСД та ОРЗ мають низку спільних та відмінних ознак. Однією із визначальних рис оперативно-розшукових заходів, що водночас є притаманними системі НСРД, є те, що вони відбуваються легально. Аегальність у цьому контексті означає санкціонованість законодавцем, надання їм статусу адекватних та прийнятних засобів правоохоронної діяльності, що за певних підстав та із дотриманням відповідних умов можуть застосовуватися уповноваженими суб'єктами. Наступною спільною ознакою є направленість на вирішення поставлених перед окремими видами державної діяльності завдань. Використовуючи притаманні їм засоби та методи впливу, оперативнорозшукова та кримінальна процесуальна діяльність в кінцевому підсумку підпорядковуються досягненню спільної мети, якою виступає забезпечення державної безпеки, чинного правопорядку та соціальної справедливості.

Під час порівняння НСРД та ОРЗ варто відзначити, що в більшості випадків вони мають однаковий режим проведення негласного, конспіративного способу. Hегласність у дано-му випадку означає неочевидність, скритність (прихованість) слідчих (розшукових) дій, що проводяться, від осіб, які в них не беруть участь, у тому числі й від співробітників слідчих і оперативних підрозділів, але передусім від об'єктів, відносно яких вони проводяться. Проведення НСРД та ОРЗ в такій формі покликане забезпечити збір відомостей про злочин і особу, що його вчинила, встановити їі місцезнаходження і місце знаходження речей і документів, що мають значення для кримінального провадження, попередити протидію розслідуванню злочину, гарантувати безпеку учасників кримінального судочинства і членів їх сімей у ситуаціях, коли проведенням слідчих дій це здійснити неможливо [3, с. 7].

Деякі відмінності у правовій регламентації, відповідно до юридичної природи оперативно-розшукових заходів та негласних слідчих (розшукових) дій, полягають у підставах їх здійснення. Виходячи з аналізу норм законодавства, оперативно-розшукові заходи в більшій мірі є засобом попередження злочинів, негласні слідчі (розшукові) дії - їх розкриття, хоча таке розмежування $є$ доволі умовним. Під час проведення негласних слідчих (розшукових) дій може бути отримано інформацію про злочин, що готується, та надалі можуть бути застосованими передбачені законом заходи його попередження (ст. 257 КПК України). У ході проведення оперативно-розшукового заходу можуть бути здобуті відомості, що спри- 


\section{Кримінальне право, кримінальний процес та криміналістика}

ятимуть розкриттю злочину, викриттю винних та притягненню їх до кримінальної відповідальності (ч. 2 ст. 99 КПК України). Спільним для оперативно-розшукових заходів та негласних слідчих (розшукових) дій також є те, що вони відбуваються із використанням методів, у загальному розумінні притаманних ОРД, також при проведенні вказаних дій використовуються специфічні засоби, що забезпечують збирання та фіксацію інформації. [4, с. 303-312].

Поряд з тим, слід звернути увагу на наявні відмінності між системою оперативнорозшукових заходів та негласних слідчих (розшукових) дій. Передусім, оперативнорозшукові заходи та негласні слідчі (розшукові) дії дещо відрізняються за суб'єктним складом, адже проводити оперативно-розшукові заходи мають право лише визначені ст. 5 Закону України уповноважені оперативні підрозділи. На противагу, проведення негласних слідчих (розшукових) дій забезпечується слідчим, що веде досудове розслідування, або за дорученням слідчого - оперативним підрозділом, де за таких обставин уповноважені суб'єкти проведення НСРД набувають повноважень слідчого (ст. 41 КПК України) [2, ст. 88].

Крім того, важливо зазначити, що НСРД та ОРЗ суттєво відрізняються за суб'єктним складом. Так, відповідно до ст. 5 Закону України «Про оперативно-розшукову діяльність» [5] суб'єктами, що мають право проводити ОР3, є лише оперативні підрозділи Національної поліції, Державного бюро розслідувань, Служби безпеки України, Служби зовнішньої розвідки України, Державної прикордонної служби України, управління державної охорони, органів доходів і зборів, органів і установ виконання покарань та слідчих ізоляторів Державної кримінально-виконавчої служби України, розвідувального органу Міністерства оборони України, Національного антикорупційного бюро України.

Аналізуючи положення п. 17 ч. 1 ст. 3, ст. ст. 38,41, ч. 6 ст. 246 КПК України, п. 1.7 Інструкції «Про організацію проведення негласних слідчих(розшукових) дій та використання їх результатів у кримінальному провадженні», затвердженої 16.11.2012 спільним наказом Генеральної прокуратури України, Міністерства внутрішніх справ України, Служби безпеки України, Адміністрації Державної прикордонної служби України, Міністерства фінансів України, Міністерства юстиції України №114/1042/ 516/1 199/936/1687/5(далі - Інструкція) [6], можна виділити суб'єктів, що уповноважені на проведення НСРД, а саме: 1) слідчий, що здійснює досудове розслідування злочину; оперативні підрозділи (тільки за письмовим дорученням прокурора або слідчого): органів Національної поліції; органів безпеки; Національного антикорупційного бюро України; державного бюро розслідувань; органів, що здійснюють контроль за додержанням податкового i митного законодавства; органів Державної кримінально-виконавчої служби України; органів Державної прикордонної служби України; 3) підрозділи Національного антикорупційного бюро України (за письмовим дорученням детектива або прокурора Спеціалізованої антикорупційної прокуратури). Таким чином, суб'єктний склад осіб, уповноважених на проведення НСРД, є значно ширшим. Також варто відзначити, що, на відміну від ОРЗ, права оперативних підрозділів під час проведення НСРД є значно меншими, оскільки без доручення слідчого, прокурора вони не можуть проводити жодних дій.

Окрім спільних та відмінних рис, між ОРЗ та НСРД, треба наголосити і на проблемі нормативного регулювання використання матеріалів ОРД як доказів у межах кримінального провадження. Для прикладу проаналізуємо практичні ситуації та переконаємось, як брак нормативного регулювання впливає на результати слідчих дій.

Відповідно до Закону України «Про оперативно-розшукову діяльність» (далі Закон) завданням оперативно-розшукової діяльності $є$ пошук і фіксація фактичних даних про протиправні діяння окремих осіб та груп (відповідальність за які передбачена КК України), розвідувально-підривну діяльність спеціальних служб іноземних держав та організацій з метою припинення правопорушень та в інтересах кримі- 
нального судочинства, а також отримання інформації в інтересах безпеки громадян, суспільства й держави.

Вказана вище норма передбачає чітке коло завдань для осіб, які здійснюють ОРД. Статтею 8 Закону встановлюється, що оперативні підрозділи наділені правом проведення ОРЗ відповідно до вимог КПК. Водночас відповідно до ч. 2 ст. 99 КПК матеріали оперативно-розшукової діяльності, зібрані оперативними підрозділами 3 дотриманням вимог Закону, за умови їх відповідності вимогам цієї статті можуть використовуватися в кримінальному провадженні як докази. Хоча ст. 84 КПК визначено, що доказами в кримінальному провадженні є фактичні дані, що отримані в порядку, який передбачено цим Кодексом. Крім того, у ст. 214 КПК наголошується, що здійснення досудового розслідування до того, як відомості будуть внесені до реєстру або без їх внесення не допускається й тягне за собою відповідальність, встановлену законом.

Отже, основна проблема для учасників кримінального процесу - це можливість використання матеріалів ОРД як доказів у межах кримінального провадження, а також законність проведення ОРЗ, та продовження ведення оперативно-розшукових справ (ОРС) після реєстрації кримінального провадження за відповідним фактом, а також - законність матеріалів, зібраних оперативними підрозділами [7].

Так, згідно зі статтею 10 Закону матеріали оперативно-розшукової діяльності можуть використовуватися, як приводи та підстави для початку досудового розслідування і для отримання фактичних даних, які можуть бути доказами в кримінальному провадженні.

Відповідно до ст. 7 Закону, у разі виявлення ознак злочину оперативний підрозділ зобов'язаний невідкладно спрямувати зібрані матеріали, у яких зафіксовано фактичні дані про протиправні діяння окремих осіб та груп до відповідного органу досудового розслідування для початку та здійснення досудового розслідування. Ця норма дає змогу використовувати матеріали ОРС як підставу для внесення відомос- тей до ЕРДР. Крім цього, ОРС закривається, а всі зібрані матеріали стають основою для проведення досудового розслідування.

Здавалося б, усе зрозуміло. Проте, згідно $з$ частиною 3 статті 7 Закону встановлюється таке: якщо ознаки злочину виявлені під час проведення оперативно-розшукових заходів, що тривають, і припинення яких може негативно вплинути на результати кримінального провадження, підрозділ повідомляе відповідний орган досудового розслідування та прокурора про виявлення ознак злочину, закінчує проведення оперативно-розшукового заходу, i після цього надсилає зібрані матеріали до відповідного органу досудового розслідування. Проте на практиці все виглядає інакше: під час застосування положень Закону та КПК, завдяки цій нормі Закону виникає безліч проблем.

Так, з одного боку, переривання певного ОРЗ може звести нанівець усю роботу оперативного підрозділу, а винна особа здобуде шанс уникнути покарання, оскільки відновлення відповідних заходів у межах кримінального провадження можливе тільки після надання згоди слідчого судді, на що потрібен час та дотримання необхідної процедури.

3 іншого боку, коли оперативні підрозділи отримують інформацію про підготовку вчинення злочину або ж фактичні дані, що можуть свідчити про вчинення правопорушення, але не скеровують матеріали до органів досудового розслідування для реєстрації кримінального правопорушення на підставі частини 3 статті 7 Закону, і продовжують у межах ОРС проводити ОР3, у подальшому ставиться під сумнів законність і допустимість таких матеріалів під час судового розгляду.

Як бути у таких випадках, однозначної відповіді не дає судова практика. Так, у постанові Верховний суд Україні (ВСУ) № 671/463/15-к від 16.03.2017 р. [8] робиться висновок, що фактичні дані, одержані внаслідок проведення оперативної закупівлі до внесення відомостей до ЕРДР, можуть бути визнані належними та використані як докази, як документи в кримінальному провадженні, за умови, якщо вони були 


\section{Кримінальне право, кримінальний процес та криміналістика}

отримані в порядку, передбаченому КПК, з урахуванням особливостей, встановлених законом «Про оперативно-розшукову діяльність».

Крім того, ВСУ зазначає, що недотримання норм процесуального законодавства на будь-якому етапі проведення відповідних заходів спричиняє визнання матеріалів недопустимими.

Брак нормативного регулювання в питаннях легалізації матеріалів ОРД у частині розсекречення документів (постанов, протоколів, клопотань тощо) та матеріальних носіїв інформації за результатами проведення ОРД стає ще однією проблемою, яка потребує негайного вирішення. Якщо з проведенням НСРД та розсекреченням їх результатів усе зрозуміло, оскільки маємо Інструкцію «Про організацію проведення негласних слідчих (розшукових) дій та використання їх результатів у кримінальному провадженні», то інструкції щодо ОРЗ не прийнято.

\section{Висновки}

Підсумовуючи все вищевикладене, варто зазначити, що під час порівняння НСРД та ОРЗ варто, в першу чергу, звернути увагу на їх спільну правову природу та витоки. Так, НСРД увібрали в себе як риси ОРЗ, так і риси слідчих (розшукових) дій. Незважаючи на спільні риси, НСРД суттево відрізняється від ОРЗ за правовими підставами проведення, суб'єктним складом, порядком використання результатів у доказуванні, формами контролю та прокурорського нагляду за їх здійсненням.

Задля можливості використання матеріалів ОРД необхідно внести зміни до Закону щодо порядку розсекречення підстав для їх проведення (ухвал та постанов), які мають гриф «цілком таємно», а також результатів проведення ОРЗ. Також 3 цією метою необхідно прийняти відповідну інструкцію чи порядок, який би створив єдину практику застосування цих питань.

Згідно з частиною 2 статті 8 Закону, прийняття рішення про проведення оперативно-розшукових заходів, подання та розгляд відповідних клопотань, проведення оперативно-розшукових заходів, фікса- ція та використання їх результатів, проведення цих заходів до постановлення ухвали слідчого судді та інші питання їх проведення регулюються згідно 3 положеннями глави 21 Кримінального процесуального кодексу України з урахуванням особливостей, встановлених Законом.

Оскільки велика кількість оперативнорозшукових дій, передбачених Законом, також містить посилання на норми КПК щодо порядку їх проведення, необхідно чітко деталізувати вищевказані положення саме в Законі. Для подальшого їх використання як самостійних та допустимих доказів потрібно їх відмежувати від НСРД.

Треба підсумувати, що тільки системний підхід до реформування оперативно-розшукового та кримінального процесуального законодавства забезпечить гармонійне поєднання норм відповідних законодавчих актів, що сприятиме удосконаленню державної діяльності із протидії злочинності та вирішенню завдань кримінального судочинства у масштабах усієї країни, а внесення змін до законодавства повинно відбуватися з урахуванням результатів наукових досліджень, проведених за цим напрямом, та за широкої участі представників зацікавлених відомств.

\section{Мiтература}

1. Скулиш Е. Негласні слідчі (розшукові) дії за кримінальним процесуальним законодавством України // Науковий вісник Чернівецького університету. 2012. Вип. 618. Правознавство. С. 108-113.

2. Кримінальний процесуальний кодекс України: Кодекс України від 13.04.2012 № 4651-VI / Верховна Раду України. URL: https://zakon.rada.gov.ua/laws/show/4651 17 \# Text

3. Негласні слідчі (розшукові) дії та використання результатів оперативно-розшукової діяльності у кримінальному провадженні: Навчально-практичний посібник / Кудінов С.С., Шехавцов Р.М., Дроздов О.М., Гриценко С.О. Х.: «Оберіг»,2013.344 c.

4. Нескромний Д.А. Негласні слідчі (розшукові)дії: юридичні та фактичні підстави їх провадження. Науковий вісник 
Львівського державного університету внутрішніх справ (серія юридична). 2015. № 2. C. 303-312.

5. Про оперативно-розшукову діяльність: Закон України від 18 лют. 1992 р.№ 2135-ХII.Відомості Верховної Ради України. 1992.№ 22. ст. 303.

6. Про організацію проведення негласних слідчих (розшукових) дій та використання їх результатів у кримінальному провадженні: Інструкція, затверджена наказом ГПУ, МВС,СБУ, АДПС, Мінфіну, Мінюсту України від 16 листопада 2012 р. № 1 14/1042/516/1199/936/1687/5/.

7. Никифорчук Д.Й. Проблемні питання проведення оперативно-розшукових заходів та негласних слідчих (розшукових) дій. Науковий вісник Національної академії внутрішніх справ. 2013. № 4. С. 173.

8. Постанова Верховного суду України №671/463/15-к від 16.03.2017 р. URL: https://verdictum.ligazakon.net.
Shai Roman

Ph.D. in Law Professor of the Department of Criminal law and procedure, Psychology and Innovative Education of the National University Lviv Polytechnic University, Lviv

SILENT INVESTIGATIVE

(INVESTIGATIVE) ACTIONS AND

OPERATIONAL INVESTIGATIVE

MEASURES: THEIR COMMON

AND DISTINCTIVE FEATURES

AND PROBLEMS OF REGULATORY REGULATION

The article is devoted to identifying problems in the implementation of covert investigative (search) actions and operational and investigative measures. The article presents the common and distinctive features of these legal institutions, points out the shortcomings of their regulation. As a result, it is noted that covert investigative (investigative) actions have a mixed legal nature and combine the features of both operational and investigative measures and investigative actions. In addition, it argues the need for more detailed delineation and legislative regulation of covert investigative (search) actions and operational and investigative measures at the legislative and departmental levels.

Key words: operative-search activity, covert investigative (search) actions, operativesearch measures, public procedural activity, official procedural actions 